IZA DP No. 4260

EU Enlargement and Ireland's Labour Market

Alan Barrett

June 2009 


\title{
EU Enlargement and Ireland's Labour Market
}

\author{
Alan Barrett \\ Economic and Social Research Institute \\ and IZA
}

Discussion Paper No. 4260

June 2009

IZA
P.O. Box 7240
53072 Bonn
Germany

Phone: +49-228-3894-0

Fax: +49-228-3894-180

E-mail: iza@iza.org

Any opinions expressed here are those of the author(s) and not those of IZA. Research published in this series may include views on policy, but the institute itself takes no institutional policy positions.

The Institute for the Study of Labor (IZA) in Bonn is a local and virtual international research center and a place of communication between science, politics and business. IZA is an independent nonprofit organization supported by Deutsche Post Foundation. The center is associated with the University of Bonn and offers a stimulating research environment through its international network, workshops and conferences, data service, project support, research visits and doctoral program. IZA engages in (i) original and internationally competitive research in all fields of labor economics, (ii) development of policy concepts, and (iii) dissemination of research results and concepts to the interested public.

IZA Discussion Papers often represent preliminary work and are circulated to encourage discussion. Citation of such a paper should account for its provisional character. A revised version may be available directly from the author. 


\section{ABSTRACT}

\section{EU Enlargement and Ireland's Labour Market ${ }^{*}$}

Ireland, along with Sweden and the UK, allowed full access to its labour market to the citizens of the accession countries when the EU enlarged in May 2004. Given the limited number of countries that opened up and the rapid pace of economic growth in Ireland around 2004, a significant inflow was expected. However, the rate of inflow exceeded all expectations. Based on census information, the number of EU10 nationals living in Ireland grew from around 10,000 in 2002 to 120,000 in 2006. Data on inflows suggests that this number could have reached 200,000 by 2008 or 4.5 percent of the population. The EU10 immigrants have very high employment rates and also have levels of education that are comparable to the native labour force in Ireland. However, they appear to earn considerably less than the native labour force and also to be in lower grade occupations. They have impacted positively on the Irish economy in terms of GNP growth. This is because wages grew more slowing in Ireland than would otherwise have been the case as a result of the labour supply increase brought about by this immigration flow.

JEL Classification: J61, F22

Keywords: $\quad$ EU enlargement, EU new member states, Ireland, immigration

Corresponding author:

Alan Barrett

Economic and Social Research Institute

Whitaker Square

Sir John Rogerson's Quay

Dublin 2

Ireland

E-mail: Alan.Barrett@esri.ie

\footnotetext{
* I am grateful for comments from participants at an IZA workshop on the topic of this volume. All errors are, of course, my own.
} 


\section{EU Enlargement and Ireland's Labour Market}

\section{Section 1: Introduction}

The last ten years have seen extraordinary growth in the Irish economy. The unprecedented period of growth lead to many changes in Ireland's economy and society. Among the most significant of these changes was the reversal of years of migratory outflows and the inflow of large numbers of immigrants. These inflows began around the mid-1990s but accelerated dramatically after EU enlargement. Given the speed with which the economy was growing around 2004, the Government decided to allow full access to the Irish labour market to all citizens of the European Union’s New Member States (EU10) from the date of accession, i.e. 1 May 2004 ${ }^{2}$. In making this decision, they were joined by the governments of Sweden and the UK only. This gave rise to a situation in which potential migrants from the EU10 had a limited number of destinations from which to choose if they wanted to work legally. With Ireland growing so strongly around 2004, it was perhaps inevitable that a large inflow from the EU10 would result.

In this chapter, we will explore the size, nature and impacts of this migratory inflow from the EU10 to Ireland. In Section 2, we present figures on the size of the inflow, relative to the population and to the labour force. In Section 3, we look at the inflow in greater detail and review what recent research tells us about the characteristics and experiences of EU10 immigrants in Ireland, with a particular emphasis on the labour market. In Section 4, we move to the issue of impact and present estimates of the impact of EU10 immigration. In Section 5, we draw the various strands together and discuss how the migration of people from the EU10/12 to Ireland may have differed from other flows, largely based on our perception that the inflow had a temporary dimension.

\section{Section 2: The Size of the Inflow}

\footnotetext{
${ }^{2}$ The same freedoms were not extended to Romanian and Bulgarian citizens when their countries joined the EU. As a result, most of the discussion in this chapter refers to immigrants from the EU10 only. On occasions, we do make reference to immigrants from the EU12 because official data is sometimes published on that basis. The precise group to which we are referring is specified where relevant throughout the text although the difference in numbers between EU10 and EU12 is slight.
} 
It is important to set this discussion of migration into Ireland in the broader context of macro-economic developments. For this reason, we begin this section by looking at Ireland's growth performance since 1990, at levels of employment and also at rates of unemployment. In Figure 1, we show growth rates of real GNP and the exceptional performance of the Irish economy is clear. Over this period, growth rates averaged 5.7 percent, thereby earning Ireland what is now the familiar label of the "Celtic Tiger". What is of more relevance for current purposes is the growth performance in the period around EU Accession. Like many countries, Ireland experience a dip around 2001/2. However, the economy soon bounced back and recorded average growth rates of just over 5 percent between 2003 and 2007.

We can get another view of the extraordinary growth performance by looking at changes in the level of employment over the same time period. In 1990, there were 1.16 million people working in Ireland. By 2007, this number had risen to 2.1 million, an increase of 80 percent. Within the period 2003 to 2007 alone, employment grew from 1.79 million to 2.1 million, an increase of almost 17 percent. As a final element in this macro-overview, we consider the rate of unemployment. The rate peaked at almost 16 percent in 1993 before beginning a downward slide through to 2001. In that year, the rate fell to below 3.7 percent. The rate did rise again after 2001 but remained low by contemporaneous European standards and only reached 4.5 percent in 2007.

We turn now to consider migration but continue to provide a longer historic picture by way of providing context for the later discussion of migration in the period after 2004. In Figure 2 we show net inflows into Ireland over the period 1987 to 2007 . We have decided to include some years from the late 1980s because in so doing we can capture that fact that as recently as then, Ireland was experiencing large population outflows. Between 1987 and 1990, the net outflow totalled 131,000 - as the population in 1991 was just 3.5 million, that net outflow was around 4 percent of the population and came on top of an additional net outflow of some 70,000 in the earlier part of the 1980s.

Even though the economy began to grow rapidly in 1994, it was not until 1997 that significant net inflows emerged. In that year, the net inflow was 19,200. In general, 
the net inflow increased up to 2001 when it reached 41,300. However, even this figure was to be somewhat eclipsed following EU Accession. The net inflow averaged almost 65,000 in the three years between 2005 and 2007.

Having looked at the economy and migration in broad terms, we now want to look in greater detail at the period 2004 to 2007 and in particular at the inflow of EU10 nationals. Our first task is to get a sense of the size of the EU10 inflow, both relative to the population in general and also relative to other immigrant groups. We begin by looking at measures of stocks in the Census’ of 2002 and 2006. We also look at information on flows, as further insights can be obtained from them.

In Table 1, we show how the population of Ireland grew from 3,858,495 in 2002 to $4,172,013$ in 2006, an increase of over 300,000 or 8 percent. We also see that the population of non-Irish people living in Ireland grew from 224,261 in 2002 to 419,733. This was an increase of almost 200,000 and so we can say that almost two thirds of Ireland's population increase between 2002 and 2006 was driven by the inward migration of non-nationals. If we include those who failed to provide a nationality in the Census questionnaires in the group of non-nationals, we see that the non-national proportion of Ireland's population grew from 7 percent in 2002 to 11 percent in 2006. We can put this rate of growth in context by noting that the immigrant share of the UK population grew by 2 percentage points over the thirtyyear period, 1960-1990 (Bell, 1997). Over the same period, the immigrant share in the US grew by 2.5 percentage points (again, Bell, 1997). Set in this context, the four percentage point increase in the share of immigrants in Ireland's population over a four year period is quite remarkable.

Turning to the immigrants from the EU10, it is not possible to an exact figure for their stocks in 2002 based on published data but it is possible to infer an upper bound figure. As shown in Table 1, we know that there were 23,105 immigrants from nonEU European countries living in Ireland in 2002. We also know that 9,101 were from Russia, Romania and the Ukraine. Hence, a maximum of 14,000 were from what we now refer to as the EU10. For 2006, we do have exact figures on the number of immigrants from the EU10. The total was 120,534, including 63,276 Poles, 24,628 
Lithuanians and 13,319 Latvians. This numbers imply that between 2002 and 2006, the stock of immigrants from the EU10 in Ireland grew by over 100,000.

In order to get a sense of the size of the continuing flow after the Census in April 2006, we can look at figures from the Central Statistics Office. In Table 2, we present CSO information on flows into Ireland between 2003 and 2008. In the years before 2004, immigrants from the EU12 were included in the "rest of world" category. However, for 2005 onwards, they are separately identified and a continuing strong inflow after 2006 is clear. In the two years ending April 2008, 86,400 immigrants from the EU12 settled in Ireland. While there was also an outflow to these countries of 16,000, the net inflow of 70,000 between 2006 and 2008 suggests that the population of EU12 immigrants would have been around 200,000 by April 2008. As the total population was estimated to be 4.42 million in 2008, this implies that immigrants from the EU 12 made up 4.5 percent of the total population. If we recall that there proportion in 2002 was less than 0.5 percent, the size of the inflow relative to the existing population is clear.

As a final view on the size of the inflow of EU12 immigrants into Ireland after accession, we can look at administrative records and, in particular, the issuing of social security numbers (known as PPS numbers in Ireland). We do this because a very different impression of the size of the inflow is generated if we take this perspective and so it is useful to explore the discrepancy between the data just presented and the administrative data.

In Table 3, we present data on the numbers of PPS numbers issued to EU 10 nationals between 2002 and 2006. It should be recalled from above that our comparison of the stocks of EU 10 nationals in the Census' of 2002 and 2006 suggested that the net inflow was in the order to 100,000. However, we can see from Table 3 that well over 300,000 PPS numbers were issued to EU10 national over this period. Even allowing for the fact that the 2006 Census was in April and so many of the PPS numbers issued in 2006 would have been to people arriving after April, there is a huge discrepancy between the Census/labour force survey data and the administrative data. However, a clue to the reason underlying the discrepancy is included in the administrative data and is shown in Table 3. 
The first column in Table 3 after the "allocation" column shows the proportion of PPS numbers issued for which no employment activity was recorded. Taking 2005 as an example, we see that of the 107,000 numbers issued, almost 20 percent were issued to people who did not subsequently show up as working. There are a number of possible reasons for this. First, the individuals could have worked in situations where they avoided tax. Second, the individuals could have looked for work in Ireland but may have moved on to the UK or back home without having worked here. A third possibility is that people applied for PPS numbers but without any intention of working, although this is probably the least likely. As the Irish Government imposed a two-year residency requirement in order to be eligible for welfare payments, there would be little point in EU 10 immigrants applying for PPS numbers unless they did intend working.

The last four columns of Table 3 show the proportion of PPS numbers issued in each year that were "active” across years, where "active” refers to some level of work being recorded. Taking 2005 again as an example, we can see that 69 percent of PPS numbers were still active in 2006, implying that 31 percent of those receiving numbers in 2005 were not working (legally at least) in 2006 and so may have left Ireland. For 2004, a similar picture emerges.

While the administrative data suggest a much bigger inflow into Ireland relative to the Census/labour force survey data, they also point to a short-term dimension in some of the migratory moves. This is an important point because it is likely to have implications which may not be captured in the way we model the impacts of immigration. As discussed in Section 4 below, the impact of immigration in Ireland has been estimated by using a statistically generated model of the labour market and by conducting simulations. If this large and temporary inflow of labour has altered the way in which the labour market functions, then the modelling approach might miss this.

\section{Section 3: The Characteristics and Experiences of the Inflow}


Having looked at the size of the EU12 immigrant inflow in broad terms, we now turn to look at the labour market dimensions in a more focussed way. We firstly want to discuss the labour-related characteristics of EU12 immigrants. We then want to look at the labour market experiences of these immigrants, in terms of their earnings and occupational attainment. In this section, we will draw on existing research and we will begin with the most up-to-date data published by the CSO.

In Table 4, we show the numbers employed, unemployed and inactive in Ireland by national groups and also the unemployment and employment rates for 2008. The first point to be taken from the table is the size of the EU12 group as a proportion of Ireland's labour force. There are 178,800 EU 12 immigrants in Ireland's labour force, which amounts of 8 percent of the total of 2,223,900. We estimated above that the EU made up about 4.5 percent of the population so the 8 percent points to a significant over-representation in the labour force. The two main reasons for this would be the under-representation of children in this immigrant group and also the high employment rate. While the Irish have an employment rate of 59 percent, the rate for the EU12 is 80 percent. This employment rate places the EU12 group above all other immigrant groups and by a significant margin. Their unemployment rate, at 6.5 percent, is above that of the Irish but could well be explained by the presence of recent arrivals and hence jobseekers.

In order to get a sense of the educational profile of EU10 immigrants, we need to draw on earlier research. Barrett and Duffy (2008) show the education levels of EU10 immigrants, along with those of other immigrants based on data from 2005. In Table 5 , we present their figures. The first point to be taken from the table is that Ireland's immigrants, in general, are relatively highly educated. We know from Barrett et al (2006) that about 30 percent of the Irish labour force have third level qualifications. Hence, the proportion of immigrant with third level qualifications, at over 40 percent, points to a high-skilled inflow. As regards immigrants from the EU10, although they have the lowest proportion of highly educated across the immigrants groups, they still compare favourably with the domestic labour force in terms of skill levels.

Although the figures on education levels presented in Table 5 point to a highly skilled inflow, research on immigration in Ireland has identified a tendency for immigrants to 
be employed in situations which do not fully reflect their skills. Of course, this finding is typical of migration research in many countries and has given rise to a number of theories such as the lack of location-specific human capital and discrimination. Such factors may be at play in Ireland but before discussing them, we will look in greater detail at the research on labour market outcomes.

The labour market experiences of immigrants in Ireland have been explored along two dimensions: wages and occupational attainment. Looking firstly at the work on wages, Barrett and McCarthy (2007a) used the Irish component of the European Union's Survey on Income and Living Conditions (EU-SILC) from 2004 to explore the earnings of immigrants generally in Ireland and also those of EU10 immigrants in particular. They found that immigrants, on average, earned 18 percent less than natives, controlling for characteristics such as gender, experience and education.

However, this aggregate figure of 18 percent hid large differences across immigrant groups. For example, when broken down by immigrants from English-speaking and non-English-speaking countries they found that the immigrant/native wage difference was essentially zero for the former group and 31 percent for the latter group. They then went on to look within the non-English-speaking group and found a wage disadvantage of 45 percent for EU10 immigrants relative to natives. This was the largest disadvantage across the different national groups.

As the data used by Barrett and McCarthy in that paper was collected through 2004, it could have been the case that some of the EU10 immigrants in the sample were interviewed prior to May 2004. As such, they would have working illegally. Even those who have arrived after May would have been very recent arrivals and so the high degree of wage disadvantage may not have been a surprise.

In order to get a second look at this issue, Barrett and McCarthy (2007b) repeated the analysis using EU-SILC data for 2005. Although the later estimate of the EU10 immigrant earnings disadvantage was lower at 32 percent, this was still a sizeable wage gap and bigger than those of other immigrant groups. Given that the sample was drawn in 2005, the wage disadvantage would not have been related to illegality. However, the possible lack of location-specific human capital is clear. The EU-SILC 
data did not include information on year of arrival but we know from the material above that most of the EU10 immigrant would have been recent arrivals.

Another view of immigrant earnings, including those of the EU10 immigrants, can be found in Barrett et al (2008b). This paper contains significant advances on the two Barrett and McCarthy papers, partly because of the data used and partly because of the techniques employed. The data used by Barrett et al (2008b) is from a survey of 50,000 employees taken in 2005, of which 10 percent were immigrants. As Barrett and McCarthy were working with samples of around 200 immigrants, Barrett et al have a vastly bigger dataset set to work with. And whereas Barrett and McCarthy relied on OLS regression, Barrett et al use quantile regression to get a richer sense of the immigrant earnings disadvantage across the earnings distribution.

As with Barrett and McCarthy, Barrett et al (2008b) find that immigrants from the EU10 have the highest earnings disadvantage across all immigrants groups. The figure they report is of an EU10 gap of 18 percent relative to natives. This is smaller than the estimates in the two Barrett and McCarthy papers. The more interesting results in the paper arise in the context of the quantile regression. The wage gap is essentially zero for the first earnings decile but rises steadily across the deciles reaching 16 percent in the highest decile. Barrett et al also run OLS wage regressions within educational categories to see if the immigrant earnings disadvantage varies across educational level. They find that immigrants with low levels of education (i.e. primary or secondary only) earn similar amounts relative to natives with similarly low levels of education. They also find that the wage gap is evident for those with postsecondary and tertiary education. They interpret these results as providing evidence that the wage disadvantage for EU10 immigrants is not about discrimination of lowskilled and vulnerable immigrants but about the failure of more skilled immigrants to fully capture returns to human capital.

As noted above, the second approach to looking at labour market outcomes was by looking at occupational attainment. Barrett and Duffy (2008) use data from Ireland's official labour force survey (known as the Quarterly National Household Survey) from 2005 to explore whether immigrants are employed in high-level occupations at rates comparable to native employees, controlling for characteristics such as age, 
experience and gender. They do this by running ordered probit regressions in which the dependent variable is a four-way categorisation of occupations, with a ranking from high-level to low level.

The first regression presented by Barrett and Duffy show that immigrants (generally) are 2 percent less likely to be in the highest level occupations and 4 percent less likely to be in the next category down, relative to natives. They are also 2 percent more likely to be in the bottom category and 4 percent more likely to be in the category second from bottom.

As was the case with the earnings results, the results for immigrants in general hide important differences across immigrant groups. And again, as was the case with the earnings results, the biggest difference between natives and immigrants arose in the case of EU10 immigrants. They were found to be 9 percent more likely to be in the lowest occupational category relative to natives and also 9 percent more likely to be in the second lowest category. The results also showed them to be 5 percent less likely to be in the highest category and 13 percent less likely to be in the second highest group.

We noted under the discussion of earnings that a part of (indeed much of) the disadvantage experienced by EU10 immigrants relative to natives may be the result of the EU10 immigrants being recent arrivals and so lacking location specific human capital. If this were the case, then the disadvantage would not be a concern and would be expected to disappear as immigrants spent longer in Ireland and accumulated the required location-specific human capital. In the data used by Barrett and Duffy, they had information on the year in which immigrants has arrived in Ireland. Hence, they were able to explore whether the occupational disadvantage disappeared over time.

The results from the EU10 immigrants, and for most of the other immigrant groups, were disappointing. Little evidence was found in support of a decline in the “occupational gap” between immigrants and natives, including those from the EU10. As Barrett and Duffy write, this could be because the time period being examined was too short. It could also have been the case that the cell sizes being used in the analysis were too small to generate statistically significant differences in the estimates. But 
either way, no evidence of labour market integration was found, in the sense in which they defined it.

Before leaving this section on the characteristics of the immigrants from the EU10, another sources of information should be mentioned. The Central Statistics Office (2008) used the Census 2006 to provide profiles of the immigrant communities from ten countries, including Poland, Latvia and Lithuania. The profiles are purely descriptive, with no regression analyses. However, they do still provide interesting insights at the nationality level, something which is missing from the studies just referred to due to aggregation of nationalities in the micro-data provided to researchers by the CSO. For example, over half of Polish males were working in either construction or manufacturing while over half of Polish females were working in shops, hotels and restaurants. Among Lithuanians, although 23 percent have a third level qualification, only 2 percent were working as professionals. This fits with the results in Barrett et al (2006) and Barrett and Duffy (2008).

Yet another interesting finding from this CSO report relates to the extent to which married immigrants were not living with their partners. Among Poles, 59 percent of married men were not living with their spouses on the night of the Census. Among Latvian married men, the corresponding figure was 48 percent. Our interest in this figure arises because it is a possible indicator of a mindset among these immigrants which sees migration as being temporary. By way of contrast, the proportion of married Nigerian immigrants who were not living with their spouses was just 8 percent.

\section{Section 4: The Impacts of the EU10 Inflow}

Research that has been conducted into the labour market impacts of immigration in Ireland has not focused on the EU Accession States in particular but has instead taken all immigrants as a block. We can, however, make some inferences about the possible impacts by drawing on that work.

The impacts of immigration into Ireland have been considered in two papers, Barrett et al (2002) and Barrett et al (2006). In the case of both papers, the approach taken 
was in along the lines of take in Borjas, Freeman and Katz (1997) in that it involves the use of a model of the Irish labour market to simulate the impact of migration and to trace through the impact on variables such as GNP, GNP per worker, employment, unemployment and wages. A key feature of the model is that it incorporates a crucial determinant of output growth in a small open economy such as Ireland, namely, competitiveness. In essence, output in Ireland is driven by its ability to attract internationally mobile capital and this, in turn, is achieved by having wages that are lower relative to trading partners. Migration impacts in the model by constraining wage growth through a labour supply increase. This wage dampening effect impacts positively on competitiveness and thereby on labour demand.

One problem with using the model to simulate the impact of immigration is that the classification of immigrants into the high-skilled and low-skilled categories is not clear-cut. In Barrett et al (2002), immigrants who described themselves as having particular levels of education were treated as being the same as natives with the corresponding levels of education. However, Barrett et al (2006) were dealing with a later flow for whom this approach would tend to overstate the true inflow of skills given that there was evidence of skilled immigrants working in occupations below their skill levels. They approached the problem in one of their simulations by using occupations as the indicator of skills as opposed to reported education levels.

In Table 6, we present what can be described as an "inferred" measure of the impact of EU12 immigration. We use the term "inferred" because what we have done is to take results from Barrett et al (2006) and we have scaled them to fit with the higher level of immigration. The figures in Table 6 show the inferred impacts of an inflow of 180,000 immigrants, with 180,000 being the number of EU12 immigrants in the labour force as of 2008.

Barrett et al (2006) present simulation results under two scenarios. In one, adjustment within the labour market occurs through the rate of unemployment and in the other adjustment is through wages. As the rate of unemployment was generally constant around 2004 (at 4.5 percent), it seems reasonable to assume that most of the adjustment to immigration was through wages. For this reason, we only present results based on that scenario here. 
The first point to be taken from Table 6 relates to the impact on employment. Although an inflow 180,000 represents 8 percent of the labour force, the simulation suggests that the impact on employment is actually much lower. Employment only increases by 4.4 percent. The reason for this is because wages fall (on average) by 7.8 percent and so there is a reduction in labour supply. Given the net increase in employment and a positive impact on output per worker, GNP is increased by close to 6 percent.

Even through this concise presentation of results from the impact simulation, it is possible to get a sense of the mechanism through which EU10/12 immigration impacted positively upon the Irish economy. The Irish economy was experiencing rapid growth around 2004 and so demand for labour was strong. In the absence of a large inflow, wages would have risen. This would have choked off the increased labour demand and so employment growth, and hence GNP growth, would have been constrained. In a sense, inward migration into Ireland helped to prevent further losses in competiveness as the deterioration in Ireland's competitiveness became a key concern in the middle part of this decade.

\section{Section 5: Discussion}

The ultimate objective of this chapter has been to explore the labour market impacts of EU Accession on the Irish labour market. In order to arrive at an assessment of such impacts, it was necessary to move through a number of steps. These steps involve determining the number who immigrated and their labour-related characteristics, analysing their labour market outcomes and then simulating the impacts using a model of the Irish labour market. The conclusions from these steps were as follows.

EU Accession occurred at a time when the Irish economy was growing rapidly and after a period of almost 10 years of sustained growth. It was against this background that the Irish Government chose to allow full access to the Irish labour market for all citizens of the EU10. Given the rapidly growing economy and the limited numbers of countries who granted such free access as of May 2004, it was perhaps unsurprising 
that a large inflow into Ireland from the EU10 commenced. The number of EU10 nationals resident in Ireland grew from under 14,000 in 2002 to over 120,000 in 2006. The continued inflows in 2007 and 2008 suggest that the population of EU12 immigrants in Ireland in 2008 was around 200,000, or around 4.5 percent of the total population.

As regards the inflow of EU10 nationals into the Irish labour market, the proportionate inflow was much higher. As of 2008, 8 percent of the labour force was from the EU12, according to the official labour force survey. However, administrative data collected through the issuing of social security numbers suggest a much bigger inflow. Between 2002 and 2006, over 300,000 PPS numbers were issued to EU10 nationals. The discrepancy between the two sources is likely to be the result of very short-term stays on the parts of a sizeable proportion of EU10 immigrants.

While the immigrants from the EU10 appear to have levels of education comparable to the existing labour force, two strands of research suggest that the EU10 immigrants are employed in occupations below what might be expected given their educations. The wage gap between immigrants and natives is largest for the EU10 nationals, with estimates of the gap ranging between 18 and 45 percent. It is also the case the EU10 immigrants experience the largest "occupational gap” relative to natives, where this is defined as occupational attainment given education levels. Combined, these results suggest that the EU10 inflow may have been low-skilled in its impact.

Drawing on previous work that has estimated the impact of immigration into Ireland in general, we have attempted to infer the impacts of the EU10 migration. The inferred results suggest that the inflow allowed for employment to increase, although by an amount substantially below the labour force increase implied by the inflow. The modelling exercise suggests that wages would have fallen, thereby diluting the employment impact as some natives withdrew from participation. As the rate of unemployment remained largely unchanged during the period under question, we would tend to believe that the impacts of immigration were felt through lower wages and hence these withdrawals from the labour market. However, it should be stressed that the model used to establish these results was estimated using time series data 
from 1966 to 2002. If it were the case that the inward migration altered the workings of the Irish labour market, then this could have been missed in the simulations.

The process within the model whereby inward migration dampened wage increases is likely to have reflected reality quite well, even if precise estimation of the impacts is difficult. As Ireland is a small and open economy, it is generally understood that competitiveness is a critical factor in economic growth. From around the beginning of this decade Ireland had been losing competitiveness as the prolonged period of economic growth resulted in wage increases above those of Ireland's trading partners. In the absence of large labour force inflows, such wage increases would have been even greater, thereby choking off labour demand.

Given the downturn in the Irish economy in 2008, the context has now changed dramatically. From a growth rate of over 5 percent in 2007, Ireland's economy will contract in 2008. This new situation gives rise to a set of questions including that of how the recent inflow will react. To date, the answer to this is unknown but the prospect of outward migration on the part of the EU10 nationals brings to mind aspects of Ireland's migration experience of the 1980s and 1990s.

Looking firstly at the 1980s, and indeed earlier, Honohan (1984 and 1993) showed how migration to and from Ireland tended to react to differentials between the rates of unemployment in Ireland and the UK whereby a stable gap between the rates tended to hold. In essence, population movements out of Ireland at times of high unemployment tended to keep the rate of unemployment lower than it would otherwise have been. With unemployment on the increase in Ireland, forecasts for 2009 see a return to outward migration ${ }^{3}$ and hence a rate of unemployment below that which would hold in the absence of that outflow (Barrett et al, 2008a).

Turning to Ireland's experience of migration in the 1990s, many of those who left Ireland in the 1980s returned during the upturn of the 1990s. One interesting byproduct of that out-and-return migration experience was an apparent increase in the human capital of those who left and returned relative to those who never left (Barrett

\footnotetext{
${ }^{3}$ See Figure 2
} 
and O'Connell, 2001). Such an effect could now be part of the labour market impacts on the EU10 as return migration occurs. However, the poor labour market situations in which many of these immigrants found themselves in Ireland, and in the UK, may mean that little human capital will have been accumulated while working away and hence may lessen any such effect. 


\section{References}

Barrett, A., A. Bergin and D. Duffy (2006), "The Labour Market Characteristics and Labour Market Impacts of Immigrants in Ireland”, Economic and Social Review Vol. 37 pp. $1-26$

Barrett, A. and D. Duffy, (2008), “Are Ireland's Immigrants Integrating into its Labour Market?”, International Migration Review Vol. 42 No. 3

Barrett, A., J. FitzGerald and B. Nolan (2002), "Earning Inequality, Returns to Education and Immigration into Ireland”, Labour Economics Vol. 9 No. 5

Barrett, A., I. Kearney, J. Goggin and M. O’Brien (2008), Quarterly Economic Commentary, Autumn, Dublin: Economic and Social Research Institute

Barrett, A. and Y. McCarthy (2007a), "Immigrants in a Booming Economy: Analysing their Earnings and Welfare Dependence”, Labour: Review of Labour Economics and Industrial Relations Vol. 21 No. 4

Barrett, A. and Y. McCarthy (2007b), “The Earnings of Immigrants in Ireland: Results from the 2005 EU Survey of Income and Living Conditions”, Quarterly Economic Commentary, Winter

Barrett, A., S. McGuinness and M. O’Brien (2008), “The Immigrant Earnings Disadvantage across the Earnings and Skills Distributions: The Case of Immigrants from the EU's New Member States in Ireland”, IZA Discussion Paper No. 3479

Barrett, A. and P. O’Connell (2001), ““Is There a Wage Premium for Returning Irish Migrants?”, (2001), Economic and Social Review, Vol. 32 No. 1

Bell, B.D. (1997), "The Performance of Immigrants in the United Kingdom: Evidence from the GHS”, Economic Journal, Vol. 107 No. 441

Borjas, G.J, R. Freeman and L. Katz (1997), "How Much Do Immigration and Trade Affect Labour Market Outcomes”, Brooking Papers on Economic Activity Vol. 1

Central Statistics Office (2008), Census 2006 - Non-nationals Living in Ireland, Dublin: Stationery Office

Honohan, P. (1984), “The Evolution of Unemployment in Ireland 1962-83”, Quarterly Economic Commentary, May

Honohan, P. (1993), “The Link between Irish and UK Unemployment”, Quarterly Economic Commentary, Spring 
Figure 1: Real GNP growth rates 1990-2007

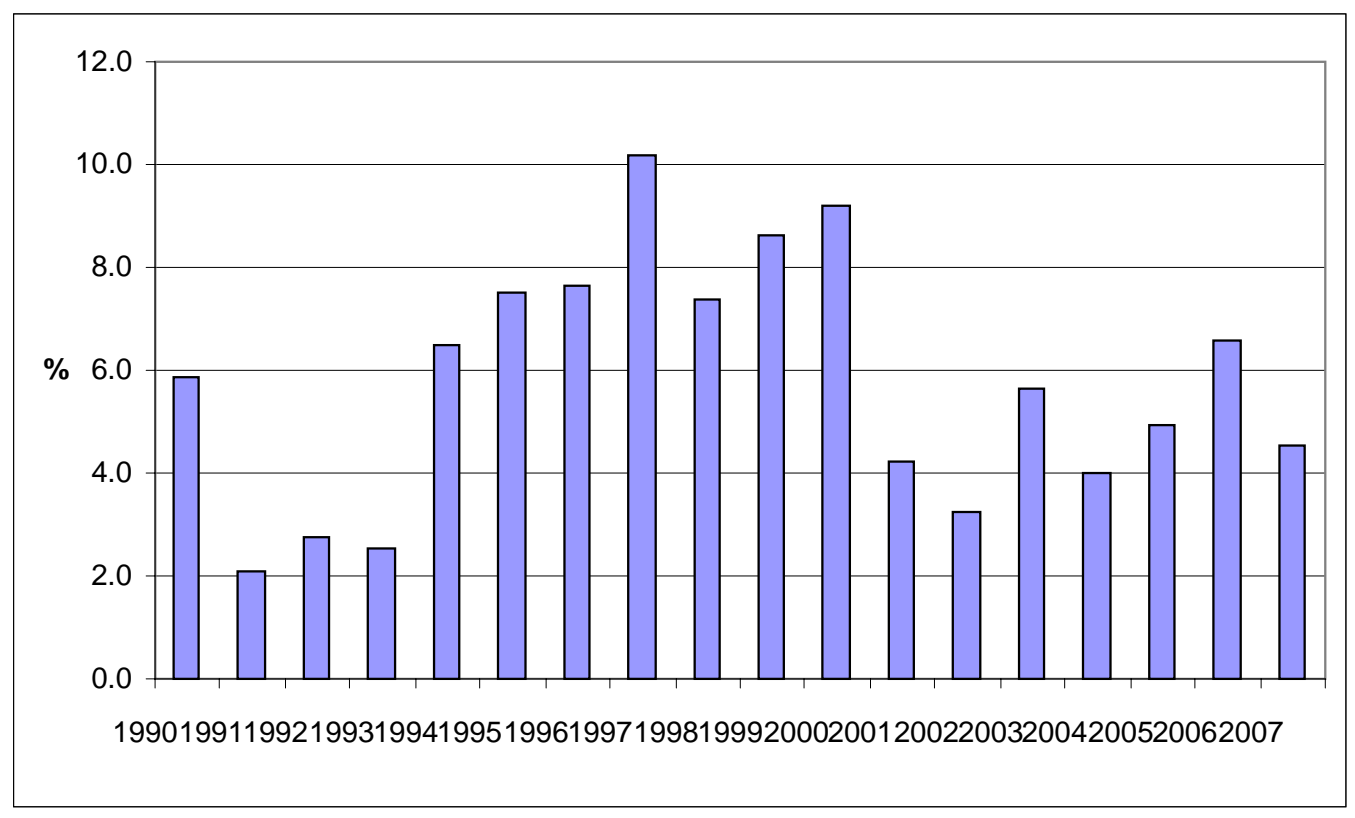

Figure 2: Net Migratory Flows 1987 to 2008, with forecast for 2009

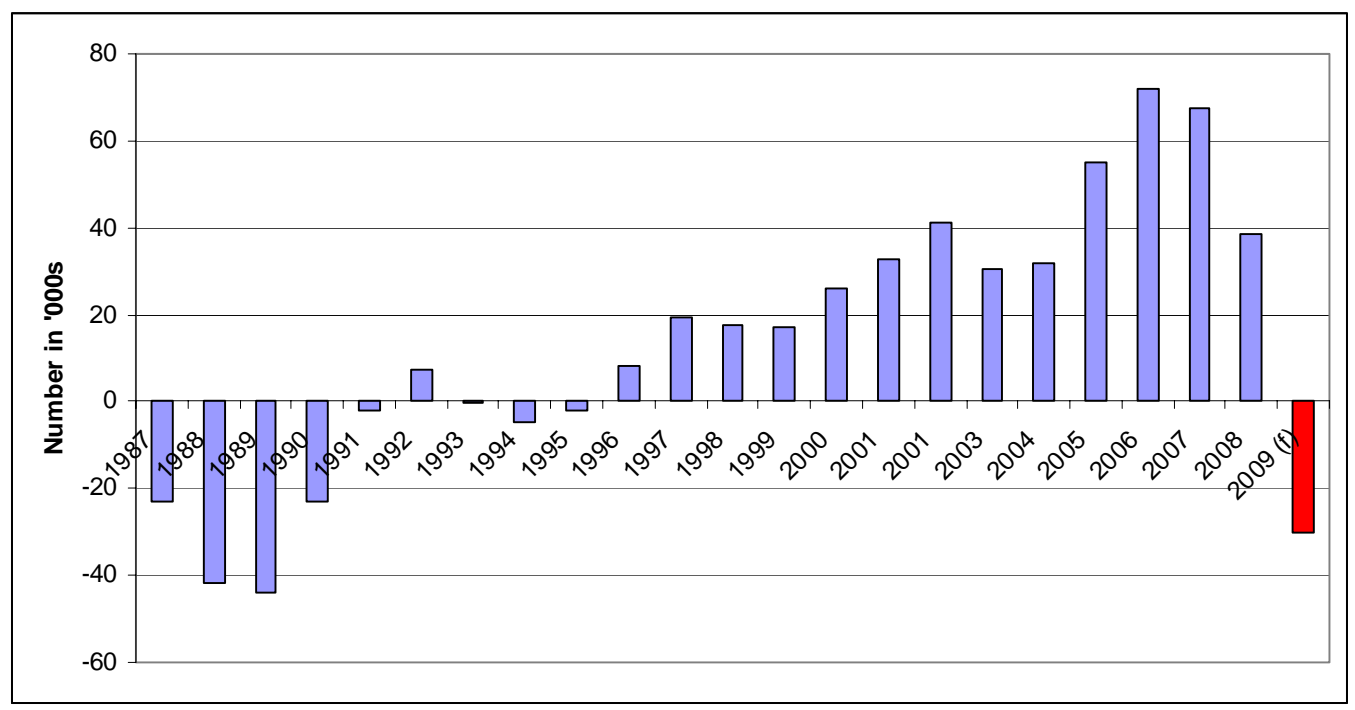


Table 1: Stocks of Irish and non-Irish national in Census 2002 and Census 2006

\begin{tabular}{|l|r|r|}
\hline & 2002 & 2006 \\
\hline Population totals & 3858495 & 4172013 \\
\hline & & \\
\hline Total Irish & 3584975 & 3706683 \\
\hline & 224261 & 419733 \\
\hline Total non-Irish & 48412 & 44279 \\
\hline Not stated & 7 & 11 \\
\hline $\begin{array}{l}\text { \% Non-Irish (including not } \\
\text { stated) }\end{array}$ & 23105 & \\
\hline $\begin{array}{l}\text { Non-EU Europe (including } \\
\text { 9,101 people from Russia, } \\
\text { Romania and Ukraine) }\end{array}$ & & 120534 \\
\hline EU 10 & & \\
\hline
\end{tabular}

Table 2: Inflows by nationality, 2003-2008 (and outflow to EU 12)

\begin{tabular}{|l|r|r|r|r|r|r|}
\hline & 2003 & 2004 & 2005 & 2006 & 2007 & 2008 \\
\hline Irish & 17.6 & 16.7 & 18.5 & 18.9 & 20 & 16.2 \\
\hline UK & 9.1 & 7.4 & 8.9 & 9.9 & 5.9 & 7 \\
\hline Rest of EU 15 & 8.8 & 13.3 & 9.3 & 12.7 & 10.4 & 8.6 \\
\hline EU 12 & & & 34.1 & 49.9 & 52.7 & 33.7 \\
\hline USA & 2.1 & 2.3 & 2.1 & 1.7 & 2.8 & 2 \\
\hline Rest of world & 22.4 & 18.8 & 11.6 & 14.7 & 17.8 & 16.3 \\
\hline Total & 60 & 58.5 & 84.5 & 107.8 & 109.6 & 83.8 \\
\hline & & & & & & \\
\hline Total outflows & 29.3 & 26.5 & 29.4 & 36 & 42.2 & 45.3 \\
\hline $\begin{array}{l}\text { Of which, } \\
\text { number to } \\
\text { EU12 }\end{array}$ & & & 0.8 & 2.3 & 7 & 9 \\
\hline
\end{tabular}


Table 3: Number of PPS numbers issued to EU10 nationals 2002-2006, along with \% where no employment activity is registered and \% with employment activity in each year

\begin{tabular}{|r|r|r|r|r|r|r|r|}
\hline & Allocation & $\begin{array}{l}\text { \% with no } \\
\text { employment } \\
\text { activity } \\
\text { 2002-2006 }\end{array}$ & \multicolumn{6}{|l|}{ \% with employment activity by year } \\
\hline 2002 & 8975 & 0.14 & 0.75 & 0.69 & 0.59 & 0.55 & 0.51 \\
\hline 2003 & 8967 & 0.12 & 0.06 & 0.73 & 0.73 & 0.62 & 0.57 \\
\hline 2004 & 58079 & 0.10 & 0.00 & 0.01 & 0.79 & 0.75 & 0.65 \\
\hline 2005 & 107451 & 0.18 & 0.00 & 0.00 & 0.01 & 0.71 & 0.69 \\
\hline 2006 & 127693 & 0.34 & 0.00 & 0.00 & 0.00 & 0.00 & 0.66 \\
\hline
\end{tabular}

Table 4: Labour Force Statistics on Ireland's Immigrants (aged 15 and over), 2008

\begin{tabular}{|c|c|c|c|c|c|c|}
\hline & Employed & Unemployed & $\begin{array}{l}\text { UE rate } \\
(\%)\end{array}$ & Inactive & Total & $\begin{array}{l}\text { Employment } \\
\text { rate (\%) }\end{array}$ \\
\hline Irish & 1770.7 & 90.7 & 0.049 & 1164.7 & 3026.1 & 0.59 \\
\hline UK & 54.5 & 4.2 & 0.072 & 41 & 99.7 & 0.55 \\
\hline EU15 & 31.2 & 1.8 & 0.055 & 10.2 & 43.2 & 0.72 \\
\hline EU12 & 167.2 & 11.6 & 0.065 & 29.3 & 208.1 & 0.80 \\
\hline Other & 84.8 & 7.2 & 0.078 & 41 & 133 & 0.64 \\
\hline Total & 2108.4 & 115.5 & 0.052 & 1286.2 & 3510.1 & 0.60 \\
\hline
\end{tabular}

Table 5: Educational Distributions of Immigrants by National Group, 2005

\begin{tabular}{|l|r|r|r|r|r|r|}
\hline & UK & $\begin{array}{l}\text { EU- } \\
13\end{array}$ & EU10 & Other & USA & $\begin{array}{l}\text { All } \\
\text { immigrants }\end{array}$ \\
\hline & $\%$ & $\%$ & $\%$ & $\%$ & $\%$ & 4.0 \\
\hline $\begin{array}{l}\text { No formal/ primary } \\
\text { education }\end{array}$ & 2.4 & 1.1 & 6.4 & 4.7 & 0.0 & 8.4 \\
\hline Lower secondary & 18.3 & 2.2 & 9.3 & 3.5 & 7.1 & 26.8 \\
\hline Upper secondary & 19.6 & 22.4 & 37.8 & 25.2 & 17.9 & 10.4 \\
\hline Post Leaving & 11.4 & 8.2 & 14.6 & 7.1 & 10.7 & 13.6 \\
\hline Third level & 15.1 & 14.2 & 12.6 & 13.6 & 3.6 & 36.8 \\
\hline $\begin{array}{l}\text { Third level - degree or } \\
\text { above }\end{array}$ & 33.3 & 51.9 & 19.2 & 45.9 & 60.7 & 100 \\
\hline & 100 & 100 & 100 & 100 & 100 & 1634 \\
\hline & 378 & 268 & 452 & 508 & 28 & \\
\hline $\mathrm{N}$ & & & & & & \\
\hline
\end{tabular}


Table 6: Inferred Impact of EU10 immigration of 180,000 labour force participants

\begin{tabular}{|l|r|}
\hline & \% change \\
\hline GNP per worker & 1.7 \\
\hline GNP & 5.9 \\
\hline Total employment & 4.4 \\
\hline Average wage & -7.8 \\
\hline
\end{tabular}

